\title{
Historicizing Environmental Security
}

\author{
Cornel Zwierlein ${ }^{1,2}$
}

Received: 7 June 2017/ Accepted: 14 October 2017/Published online: 15 December 2017

(C) Springer International Publishing AG, part of Springer Nature 2017

Environmental security is a bountiful but seldom narrowly defined notion within current security studies (Barnett 2001, pp 25-49; 2007; Dyer 2001; Allison 2014; Deudney 1990; Weintraub 1995; Dyer 1996; Carrapatoso 2011; Lautensach and Lautensach 2014). The link between awareness of environmental problems and security is usually historically situated as a part of the emergence of post-World War II global environmental politics, a major step being the 1972 Stockholm conference. ${ }^{1}$ Environmental security covers security politics that investigates either the security of states or that of humans from direct or indirect environmental threats (Carrapatoso 2011, p 211f). The debate about whether the major actor and object of security studies should be the state or people, as has been the agenda of the human security approach since at least the 1990s, returns here with regard to the environment. The other distinction between direct or indirect threats concerns the question of the politics of prevention, or security measures immediately taken during emergency situations following a natural catastrophe, or long-term threats such as conflict, war, food shortages, and migration as actual or supposed consequences of either environmental degradation or climate change. As such, 'environmental security' could be understood as a sub-field of the human security agenda, with the very broad definition of human security as "freedom from fear and want" also encompassing natural hazards and threats (Paris 2001; Owens 2012, with

\footnotetext{
1 There is not yet, as far as I see, a global history of the Stockholm conference, but cf. the national and comparative studies (Hünemörder 2004 (US, Germany); Kupper 2003; and more recently Manulak 2015 (Canada)).
}

English editing by Stephen Walsh.

Cornel Zwierlein

cornel.zwierlein@uni-erfurt.de; cornel.zwierlein@rub.de

1 Max-Weber-Kolleg Erfurt, Steinplatz 1, 99089 Erfurt, Germany

2 Historisches Institut, Universitätsstr. 150, 44801 Bochum, Germany 
the literature in note 8; quite teleologically framed is MacFarlane and Khong 2006; cf. then Schuck 2011; Zwierlein 2012). However, when it comes to the question, as is the case here, of how to historicize such a concept in the longue durée, it is more helpful to keep 'nature' as the term, more apt to embody the development of human perception and awareness of (his) nature, as our complement to 'security', rather than 'environment'. 'Environment' in its deeper and wide sense of the ecological system in its adaptive coexistence with (industrialized) human society, as it is used today, is not found as such in premodern sources. Tracing its possible first genealogical roots from the concepts of the oikos, the oiko-nomia to early modern transformations, and then illustrating its radical semantic change and broadening around 1900 would necessitate more time, space, and intellectual effort in comparison with our needs here; it would be a misleading detour - though in terms of intellectual correctness, it would be necessary (Trepl 1987; Glacken 1967). A further important element, seldom explicitly reflected about in political sciences today when dealing with environmental security, because it seems to be a tacit presupposition of the term, are its roots in international relations and a global system of politics. Reflections on 'environmental security' often start from the UN perspective of how to link and harmonize the interest-based politics of individual states to the needs of global environmental politics and the future of the inhabitants of a threatened earth. This is clearly a point of view that needs its own historicization for periods prior to the 20th century.

As the history of security in general is still just emerging, curiously younger than 'security studies' as a field of political sciences (Daase 2012, p 389), not many methodologically sensible attempts exist to historicize those concepts that serve today as powerful terms of agenda setting in international politics. Some earlier efforts on the more general term of 'human security' have shown the problems, strengths, and weaknesses of those existing attempts (Zwierlein et al. 2010). On environmental security in a narrower sense, still less exists, foremost, if we are thinking about 'environmental history' in general and not just the post-1972 history of international environmental politics, when the concept and term was already used more or less in the same way as today. A chapter in Dalby's book on environmental history may be taken as such an exceptional attempt to include a historical perspective on its subject (Dalby 2002, pp 69-73). Among environmental historians, 'security' is usually studied as a problem linked to the sub-field of the history of natural hazards and catastrophes. However, the link between 'interterritorial', international or, finally, global security and the environment is not at the center of interest or, if it is, only for the most recent times.

Contributions to the history of security often do well to recall some basic facts about their principal notion and the concept itself. Here, some consensus exists that, if not the word, then at least the notion of 'security' is strongly linked to (early) modern times (Conze 1984; Zwierlein 2013, p 68), with the emergence of the territorial state and eventual inter-territorial state systems. This can be challenged, and one can find instances of 'security politics' in earlier eras of Western history, and across the world while the term as such is not used (as always in the history of concepts). Still, it is quite important to recognize that the widespread use of 'security' as a guiding principle of collective bodies, administrations, and 
governments is more or less as old as that what one is used to call 'the state' itself. The philology of security is currently converting the older Epicurean-Ciceronian roots of the term securitas into a sophisticated heuristics: it stresses the plurality of its meaning, starting first as the negation of cura (care) which leads to notions far away from and even contrary to the modern term's association with safety (Hamilton 2013). The idea of collective security in the form of the securitas publica became one of several guiding principles not in Roman Republican, but Roman Imperial politics (Instinsky 1952; Rivière 2007). However, in Western classical antiquity, as well as in Western 'medieval' times, the term was largely overshadowed by the concept of peace; the inter-personal rather than territorial concept of pax prevailed. In this context, it is telling that still at the beginning of the 17th century, in England as well as in Germany, one understood those old roots of securitas, meaning the absence of care and carelessness in its negative sense. As far as I can tell, Shakespeare only used "security" in this meaning. ${ }^{2}$ A concept of collective security that means the establishment, positive care for and maintenance of a sphere of living for citizens of a commonwealth by a government and its administration, so that the territory is free from threats seems to have grown slowly, first in Renaissance Italy, then in a Europe that was beginning to conceive of itself in a form of trans-personal spatialized perception of politics as consisting of states. Again, de-centering and anti-'Europeanizing' perspectives can be used to challenge this, and saying it does not necessarily mean adopting a teleologically framed history that hails the achievements and 'gifts of Europe' to World History.

Still, international politics all over the world uses such terms today, and if 'environmental security' challenges, the 'state-based' approach of traditional political sciences, just as the promotors of 'human security' have been doing, and a historicizing of the concept has to cope with the historical fact just mentioned: that 'security' as such has those same roots-regionally and chronologically different, but not ahistorically and eternally given - as that very concept of statehood.

If security alone as one of the three elements combined in 'environmental security' posits already complex and manifold problems for historicization, the same holds true for 'environment', or an awareness of environmental issues. Environmental historians have drawn out different paths of the history of that awareness. The history of ecological thoughts and of 'nature' in general is one way (Glacken 1967; Worster 1994). Here, beyond the field of a history of ideas in a narrower sense, the subjects that have attracted a great deal of attention include different forms of late romantic social movements grounded in the more 'national' way of thinking about 'Heimat' (Germany) (Schmoll 2004; Dominick 1992) and the confrontation between the wilderness and civilization as a formative process of nation-building along 'nature's frontier' since the 17th century (Turnerian theses, often discussed in US environmental history, Waechter 1996; Cronon 1995; Epstein Popper et al. 2000). Still, more important is the history of the nexus between

\footnotetext{
2 "Security gives way to conspiracy" (Julius Caesar II, 3, 6, Shakespeare 1955); "And you all know, security/Is mortals' chiefest enemy" (Macbeth III, 5, 32f., Shakespeare 1984). This also holds true for Germany, where we find "securitas" as "carelessness" in sermons of Lutheran preachers: "Dann es befindet sich bey uns eine Magna securitas, ein grosse Sicherheit/da man gantz sicher dahin und in den Tag hinein lebet" (Böck 1655, p 28).
} 
economic thought and praxis and 'nature/environment'. Historians of forestry have taken an early lead in this field, showing that within 18th century academic cameralism, early forms of sustainability thought had developed. ${ }^{3}$ One might distinguish several steps, here, perhaps three: (a) between that early cameralist thought in which state, society, and economics were seen as an interconnected field and the 'sustainability of nature' was mostly thought of in terms of how one could cultivate best the woods for guaranteeing the highest possible extraction over a long period; (b) between an early national-liberalist form of economic thought in which economics was seen as a self-regulated sphere that had to be simultaneously kept from state influence and protected by the state, while 'nature' became more and more the target and victim of untamed resource extraction; (c) and between a late 17 th-century inclusion of scientific, social, and early 'environmentalist' tempering and taming of that liberalist dissociation of state and economics that led to early forms of policies to protect and conserve nature for its own sake (or for humans, but not for the economic purposes of humans-Stuber 2008; Zwierlein 2011, pp 306-314). To that rather national perspective of the growth of early environmentalist movements, since the 1990s scholars have been adding the question about the role of early imperial and global experiences of biodiversity and human influence on environmental degradation played on early discourses and practices of conservation, sustainability, and protectionism (Grove 1995). The next step was to show how the later forms of scientific colonialism, mostly developed around 1900 in the French, British, Dutch, and German colonies, and that continued to prevail in the Inter-War period, were a nucleus of the discourses and institutional agenda setting of the UN, gradually linking developmental policies with concepts of environmental conservation. ${ }^{4}$ Thus, the key term of the UN's 1987 Brundtland report was to connect, in a paradoxical formula, two concepts implicitly opposed to each other, the one aiming, in its extreme forms, at stable state economies, the other implying some form of progress-sustainable development-has very old roots. Nevertheless, if we consider the great wealth of historical contributions to the development of environmental(ist) thought and practice, we still will not find 'security' playing a great role in that literature. Only if we consider signs of caring for economic stability or growth, fear of, and protection against, instability and threats possibly created by nature's infertility or other instances of negative economic repercussions, we might translate already existing research into contributions to a history of 'thoughts on environmental security and safety'. However, the literature usually does not address this matter in such terms. One has to 'securitize' one's own way of

\footnotetext{
${ }^{3}$ One usually cites Carlowitz's Sylvicultura oeonomica (1713) for the first explicit reference to the principle of sustainability, (Sieferle 2001); the link between that narrower context of German forestry cameralism and its transfer into the global contexts of nineteenth century British India is provided by Rajan (1998).

4 This is the argument of Anker (2001); but the link between early developmental policies, conceived first for the purposes of better and economically more efficient colonial administration, and the later postWW II discourse of governmentalities of environmental conservation and developmentalism between the 'First' and 'Third World' has grown recently into a broader field of research: Robin (1997), Tilley (2003), Beinart and Hughes (2007), pp 200-213, Beinart et al. (2009), Speek (2014), Wöbse (2011).
} 
reading and one's own focus on what is written about the 'economics of nature'-to use the term of the Copenhagen school (Buzan and Wæver 1998).

A vast amount of literature certainly exists about the growth and development of the state system(s) and of international history. Since the late 1990s, scholars have been trying to also to rediscover forms of 'international' history in the ancient and medieval periods, with a newly re-enforced attention to (proto-)diplomatic history and the history of communication, alongside the more traditional themes of the transformation of what had been the 15th century Italian pentarchical system into the so-called (and historically perhaps never really realized) 'Westphalian system' (Schmidt 2011). Attention has also been devoted to the 18th century European pentarchy and then the forms of globalization and the formation of the 20th century international order, whose structure is widely debated. ${ }^{5}$ It is impossible and not my aim here to trace a consistent overview of that development. However, one thing is clear: issues of 'nature' or 'environment' were either not an object of interstate politics and diplomacy in earlier times or research has seldom taken notice of it before the 20th century. Asking about how many books exist on 'Bismarck's European foreign politics and the environment' or about the same for the 17th century diplomatic peace congresses sounds odd, as both themes do not obviously seem to have anything to do with each other. There is a good body of the literature on 'colonial (proto-)environmental politics' for some parts of the 18th and 19th century, but rather from the above-mentioned perspective of one colonial state (e.g., British forestry politics in India, Rajan 2006; Barton 2002; Sivaramakrishnan 2008, Environmental legislation in Germany's colonies, Wächter 2008; Gißibl 2006). Only recently have some attempts to address the question of a history of environmental transregional or international history emerged. Usually, the emergence of international environmental politics is still chronologically situated within Cold War Contemporary History, usually taking the 1970s as the times of its real beginnings (Schulz-Walden 2013). Studies that have addressed the 19th and early 20th century international cooperation concerning 'conservation' are an exception (Dorsey 1998; Dorsey 2007; the special issue of Diplomatic History 32, 4 (2008); Knab and Forclaz 2011). An archaeology of medical topographical perceptions within global networks like the French praeter-imperial consular system might lead on a path to earlier periods. The concept of 'environment' is then rather a Hippocratean one, linked to the problem of disease control and the observation of how epidemics spread. This is an early example of international environmental security (Arner 2013). Still, there are risks here of transforming the history of acclimatization and epidemiological discourses into that of 'environmental security' due to the link of the 'faux ami' of a changing notion of 'environment' (it is a methodical error to follow a conceptual isomorphism instead of homologies; however, there are some possible direct genealogical links: Sellers 1997; Sellers and Melling 2011).

\footnotetext{
5 To methodically realist and constructivist options, we might add the plurality of structural conceptions, ranging from positions to understand the International Order as 'new medievalist anarchy' to insist on the re-strengthening of the plurality of separate nation-states. Cf. the classical Bull (2002), and Ashworth (2002), Prichard (2011) for differently focused overviews on the state of debate between realist, idealist; state and antistatist approaches.
} 
It is thus correct to summarize that, broadly speaking, 'environmental security' as a matter of international history seems to enter histor(iograph)y like a deus ex machina only after 1945 .

All three elements, 'security', 'environment', and 'international history', as they are combined in the contemporary notion of 'environmental security', therefore, have their own complex history and historiography-but they are, or seem to be, distinct and separated from each other in a long-term approach. Maybe, this is because the combination of an awareness of the threats possibly exercised by nature or by the side effects of human action on natural processes on a global scale could only be recognized in the era of fully fledged globalization and interconnection. Still, it should be worth trying to historicize the combinatory concept as such, admitting that it will not be fitting to project the current concept unchanged onto earlier periods and different regions and societies and that one might always just find the linkage and intersection of aspects and parts of those three elements. It seems that there are several places to look for those embryonic forms, while others will not be of help. Within Roman History, one might think, as an issue to look at, of the early politics of grain trade and supply across the large dimensions of the empire. However, neither the concept of securitas publica was linked to that nor the germs of the ius inter gentes, whose implications and dimensions as a forerunner of modern international law are still widely discussed (Ando 2008). The reason for this lies in the far more imperial then inter-territorial dimension of Roman governance. In contrast, historians of ancient Greek concepts of 'collective security' have pointed to instances, where the city states, with their respective territories, negotiated treaties and maintained guards (horophylakoi), not only against the problems of thieft, robbery, piracy and to ensure the security of travelers and merchants on the roads going from one territory to another territory, but they also inserted specific clauses about the protection of natural resources (the fields, trees, etc.) from plunder (Chaniotis 2008, p 108, p 120 with note 60 for further references). While this is still a very specific practice without a connection to what the history of ideas terms as 'ancient ecological thought' with Aristotle and others (Glacken 1967; for the ecological situations Sallares 1996), it seems to fit best as a manifestation of a conscious, though pre-theoretical, application of the threeelement-scheme of Economy, Nature and 'International system' during those times. For the premodern, medieval, and early modern periods, the historiography on coping with natural disasters has paid some attention to proto-concepts of 'environmental security'. Scholars have traced century-long processes during which tacit and local knowledge of inhabitants under constant threat by floods and earthquakes was consciously or unconsciously elevated from the local to the regional and to the state level (e.g., Rohr 2007, p 372-375; Allard 2007; Barrué 2002; Quenet 2005, p 254-263). Historical anthropology and the History of Science in early colonial contexts have transferred this question to non-European contexts, finding "seismic cultures" of long-term adaptation to earthquake threats not only in Italy but also in the pre- and early colonial Philippines, and discussing to what extent older Aztec dike building knowledge was used or neglected by the Spanish 
conquerors to protect the most important city Tenochtítlan from flooding. ${ }^{6}$ Only in parts of that literature, is an inter-territorial or international dimension addressed, ${ }^{7}$ but such questions are starting to be on the current agenda of research. The establishment of premodern inter-regional risk communities regarding threats in addition to flood and fire damage that could lay waste to entire communities is seen as one step leading to inter-national and later global communities of solidarity, postdisaster relief and insurance networks (Zwierlein 2011, pp 263-278; Pearson and Yoneyama 2015; Schröder 2006; Zwierlein 2017). This was partially embeddedfrom the 18th century-in a growing philanthropic discourse, cultivated in philanthropic societies and associations as they spread across the world during the second half of the century, mostly within the formal and informal parts of the British Empire and later Anglo-American networks of communication (Moniz 2006, p 25f, pp 89-96, p 165, p 171). This proto-humanitarian discourse is at some points even close to the post-modern discourse of human security as Rothschild has argued (Rothschild 1995). That (partially) natural disasters like the tremendous city fires of the 19th century European metropoles and American cities (e.g., San Francisco 1906-Bankoff et al. 2012) could spontaneously generate global networks of financial post-disaster charity is a part of the story of how 'humankind' started to conceive itself as globally connected, as partially globally responsible for each other and globally threated by nature. In earlier times, however-and this holds still true for the famous Lisbon earthquake of 1755-perception of the event in news communication might have been global, but no network, no concept of transregional preventive or post-disaster security measures was active. The growing field of the history of early state and supra-state institutions of security production, among them insurance, is here a field for future research: at least the 18th and 19th century private insurance companies following the British model (in contrast to the German cameralist insurance institutions, whose radius of action was coextensive with the borders of a territory) were early institutional agents of thinking about natural hazard risks in their trans-territorial impact and dimension. Today, it is the NatCatService of one of the few global Reinsurances that annually publishes the major global overview on disasters and losses that is orientating the perception of politics - perhaps one of the best single picture visualizations of 'environmental security' as a problem (Hannig 2016, 256). 2017 has again been a year with a huge number of natural catastrophes, including hurricanes Harvey, Irma, Maria, and the massive earthquake in Mexico. All these natural catastrophes have been present around the globe to everyone, thanks to non-stop media coverage as well as discussions with insurers and re-insurers, questions of national flood insurance and

\footnotetext{
6 Bankoff (2007) on the 'earthquake baroque' as a hybrid adaptation of the Western Baroque architecture on tacit indigenous knowledge about earthquake vulnerability. For the second example from the early Spanish Empire, Miller (2007) stressed the neglect of tacit Indian knowledge by the Spaniards causing major floods and being thus a cause for a decreasing state of the city's security level; Barrera-Osorio (2010) is more interested in the internal German/Spanish/Dutch competition of recognition as experts by the Spanish government.

7 It is telling that for the nineteenth and early twentieth century US, the history of coping with disaster damage relief concentrates mostly on the passing from a local and intra-state to the federal level, not addressing any international implications: Dauber (2012)—but the process of successively enlarged spatio-regional extension of the sphere of security agenda described is at least analogous.
} 
issues associated with risk zoning. These questions and discussions have once again been brought from the dusty desks of experts to the immediate interest of each family that had lost their homes and property. The Natural Hazard map of 2017 will show strong impacts across the Americas ${ }^{8}$ - but early 18th century insurances had not yet developed such forms of visualization for larger regions. ${ }^{9}$

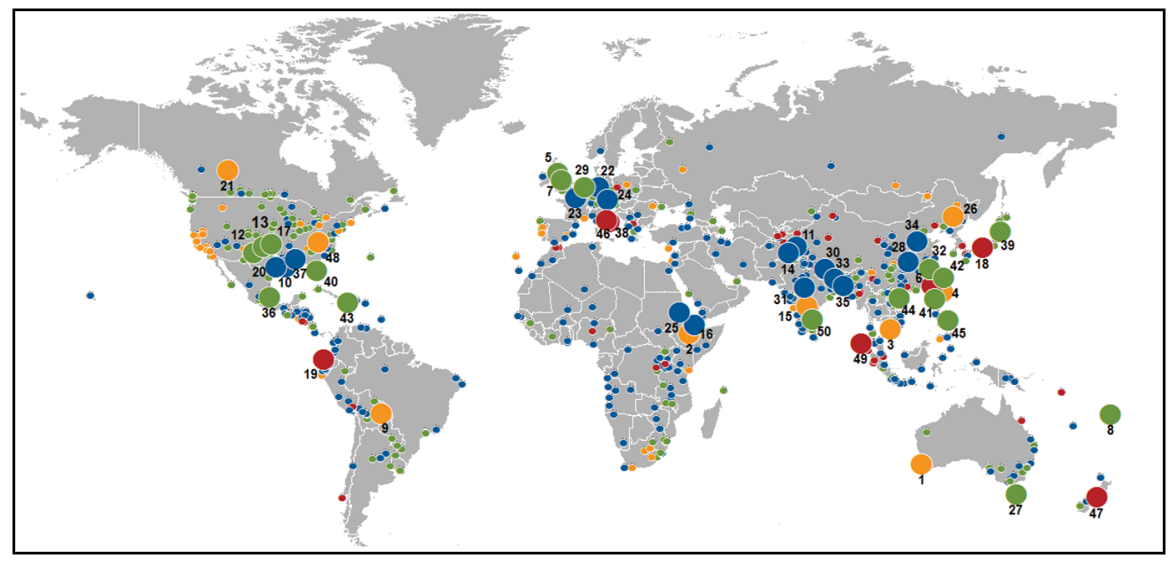

'Environmental Threat': Natural Catastrophes worldwide 2011-2016, MunichRe NatCatService

Still, in forms of narrative descriptions and of archiving the damages over time, they first created such an institutionalized 'picture' and awareness of threats and the amount of damages involved.

Today, one of the major issues in discussions of environmental security is the threat to humankind posed by climate change and its impact (cf. only, UNHSP 2007, 2011). Some points of caution need to be clarified regarding this topic during our attempt to historicize 'environmental security'. First, one can tell the story of scientific discoveries-such as John Tyndall's 1860 discovery of how ozone, carbon dioxide, and water vapor absorb infrared rays differently and contribute by that to the temperature of the atmosphere-this would be a pre-history of our discussion of the industrial climate threat created by gas emissions (Hulme 2009, pp 43-45). While these discoveries are still used as a starting point for our own scientific epistemic matrix, this means projecting current explicatory schemes and causal relationships related to 'environmental security' back into time, and while Tyndall was perhaps trying to understand the atmosphere, he had no idea of its security implications and global impact of human industry on it. In contrast to this, early discourses on climate, hygienics, and medical acclimatization seem more comparable. Admittedly, these ideas are today largely 'transcended' in terms of granting

\footnotetext{
${ }^{8}$ Walsh (2017), Fessenden et al. (2017).

${ }^{9}$ But hazard mapping as the visual representation of urban risk zones, implying the spatial estimation of vulnerability degrees and thus an inverse picture of the perception of the safety aimed for, has its origin within the British-American fire insurance business around 1800: (Manen 2014, p 172, Monmonier 1997, p 286; Tebeau 2003, p 89-125).
} 
them any scientific truth, but at their time, they evinced the same concern with the interconnection of security, an awareness of environmental threats and the international dimension (cf. the respective section below in my contribution). The perception of the large difference of weather conditions led to the dissolution of received classical concepts into an early modern theory of acclimatization; later, a colonial medical topography evolved that was essential for city planning as colonial precursors of post-colonial discourse on the (environmental) security of cities (Lind 1811; Johnson 1827; Arnold 1993; Arnold 1996; Barrett 1991; Bewell 1999; Harrisson 1994; Yeoh 1996; Peckham and Pomfret 2013). It is possible to understand this as a part of the pre-history of environmental security discourse, because in fact, these theories consistently evolved with regard to the security of human bodies, of the agricultural and horticultural economy, and the well-being of commonwealth(s) as a whole.

In contrast to that large parts of the early modern mainstream politico-economic discourse were not concerned with their international dimensions, as was the case for physiocracy or cameralism. Even early British politico-economic discourse was concentrated on local or regional units [the same holds true for demographic thought, which usually did not analyze total populations, but fractions of them, smaller subpopulations, (McCormick 2016, p 28)]. However, the strong connection of economic, politico-imperial thought about security, the international dimension of empire building, plantation, settlement, and agricultural concepts of improvement was developed earlier and brought about in the British case, embedding the question of 'security' more profoundly within an international framework. This reflection leads, therefore, to a prudent heuristical deepening of the approach already worked out concerning the historical link between post-colonial developmental politics, environmentalism, and the colonial and imperial pre-World-War forms of similar governmentalities. Therefore, a history of 'environmental security' in the longue durée can be traced back in time by following the paths of early colonialism and the establishment of the early European trading and settler empires. However, certainly, that genealogical link of 'environmental security' to imperial economies remains rooted first of all in the fears and efforts of the growing national state, being the core of those empires: the policies adopted by early modern governments, the political arithmetical thought concerned with the nexus between economic speculation, agrarian sustainability, and the security against unforeseen environmental threats were conceived first mostly with regard to the closed territories such as France. The contributions for the late modern and contemporary period show, by contrast, that environmental security has now become an issue treated differently, on a multi-level scale from the local to the global, with all levels being entangled and interconnected. Differently from early modern concerns for food and supply crises in purely economic and populationist terms, every political and even private actor on the local level is aware of possible or probable links between their 'small world' and global developments. This seems banal, but from the point of view of the historian, this difference opens up a wide horizon of issues and problems, on a methodological and operative level of historicization: historicizing environmental security has just begun. 


\section{References}

Allard P (2007) Secours, indemnisation, réparations avant la généralisation des assurances. L'exemple des inondations d'Arles entre 1755 et, 1856. In: Favier R, Pfister C (eds) Solidarité et assurance. Les sociétés européennes face aux catastrophes (17e-21e s.). Publications MSH-Alpes, Grenoble, pp 247-268

Allison JE (2014) The study of global environmental politics. Strategies for research and learning. In: Harris PG (ed) Routledge handbook of global environmental politics. Routledge, London-New York, pp 56-71

Ando C (2008) Aliens, ambassadors, and the integrity of the empire. Law Hist Rev 26(3):491-519

Anker P (2001) Imperial ecology: environmental order in the british empire, 1895-1945. Harvard University Press, Cambridge

Arner K (2013) Making global commerce into international health diplomacy: consuls and disease control in the age of revolutions. J World Hist 24(4):771-796

Arnold D (1993) Colonizing the body: state medicine and epidemic disease in nineteenth-century India. Berkeley University Press, Berkeley

Arnold D (ed) (1996) Warm climates and western medicine: the emergence of tropical medicine, 1500-1900. Rodopi, Amsterdam

Ashworth LM (2002) Did the realist-idealist great debate really happen? a revisionist history of international relations. Int Relat 61:33-51

Bankoff G (2007) Fire and quake in the construction of old Manila. Mediev Hist J 10:411-427

Bankoff G, Lübken U, Sand J (eds) (2012) Flammable cities: urban conflagration and the making of the modern world. University of Wisconsin Press, Madison

Barnett J (2001) The meaning of environmental security. Zed Books, London/New York

Barnett J (2007) Environmental security and peace. J Human Secur 3:4-16

Barrera-Osorio A (2010) Experts, nature and the making of antlantic empiricism. Osiris 25(1):129-148

Barrett FA (1991) Lind's medical geography. Soc Sci Med 33:347-353

Barrué M (2002) Le risque vécu et construit en pays montagnard pyrénéen [...]. In: Favier R (ed) Les pouvoirs publics face aux risques naturels dans l'histoire. Publications MSH-Alpes, Grenoble, pp 71-104

Barton G (2002) Empire forestry and the origins of environmentalism. Cambridge University Press, Cambridge

Beinart W, Hughes L (2007) Environment and Empire. Oxford University Press, Oxford

Beinart W, Brown K, Gilfoyle D (2009) Experts and expertise in colonial Africa reconsidered: science and the interpenetration of knowledge. Afr Aff 108:413-433

Bewell A (1999) Romanticism and colonial disease. John Hopkins University Press, Baltimore

Böck S (1999) Eine Christliche Erinnerungs- und Gedächtnus-Predigt [...]. Kühne, Ulm

Bull H (2002) The anarchical society: a study of order in world politics, 3rd edn. Columbia University Press, New York

Buzan B, Wæver O (1998) Security: A New Framework for Analysis. Rienner, Boulder

Carlowitz: Sylvicultura oeonomica (1713)

Carrapatoso A (2011) Security and the environment: what is at stake? In: Schuck C (ed) Security in a changing global environment: challenging the human security approach. Nomos, Baden-Baden, pp 211-231

Chaniotis A (2008) Policing the hellenistic countryside: realities and ideologies. In: Van Wees H (ed) Sécurité collective et ordre public dans les sociétés anciennes. Fondation Hardt, Vandœuvres, pp 103-145

Conze W (1984) Sicherheit, Schutz. Geschichtliche Grundbegriffe: Historisches Lexikon zur politischsozialen Sprache in Deutschland, vol. 5. Klett-Cotta, Stuttgart, pp 831-862

Cronon W (1995) The trouble with wilderness; or, getting back to the wrong nature. In: Id (ed) Uncommon ground: rethinking the human place in nature. Norton, New York, pp 69-90

Daase C (2012) Die Historisierung der Sicherheit. Anmerkungen zur historischen Sicherheitsforschung aus politikwissenschaftlicher Sicht. Geschichte \& Gesellschaft 38:387-405

Dalby S (2002) Environmental security. University of Minnesota Press, Minneapolis

Dauber ML (2012) The sympathetic state: disaster relief and the origins of the American welfare state. Chicago University Press, Chicago 
Deudney D (1990) The case against linking environmental degradation and national security. Millennium 19:461-476

Dominick R (1992) The Environmental Movement in Germany. Prophets and Pioneers, 1871-1971. Indiana University Press, Bloomington

Dorsey K (1998) The Dawn of Conservation Diplomacy: U.S.-Canadian Wildlife Protection Treaties in the Progressive Era. University of Washington Press, Seattle

Dorsey K (2007) The potential and the reality of safeguarding the environment by american diplomacy. In: Lehmkuhl $\mathrm{U}$, Wellenreuther $\mathrm{H}$ (eds) Historians and nature: comparative approaches to environmental history. Berghahn Books, New York, pp 277-295

Dyer H (2001) Environmental security and international relations. Review of International Studies 27:441-450

Dyer HC (1996) Environmental security as a universal value: implications for international theory. In: Vogler J, Imber MF (eds) The environment and international relations. Routledge, London, pp 22-39

Epstein Popper D et al (2000) From maps to myth: the census, turner, and the idea of the frontier. J Am Comp Cult 23:91-102

Fessenden F, Gebeloff R, Walsh MW, Griggs T (2017), Water damage from hurricane harvey extended far beyond flood zones. New York Times. https://www.nytimes.com/interactive/2017/09/01/us/ houston-damaged-buildings-in-fema-flood-zones.html. Accessed 10 Oct 2017

Gißibl B (2006) German Colonialism and the beginnings of international wildlife preservation in Africa. In: Zelko F (ed) From 'Heimat' to 'Umwelt': new perspectives on german environmental history. German Historical Institute, Washington, pp121-143

Glacken CJ (1967) Traces on the rhodian shore: nature and culture in western thought from ancient times to the end of the eighteenth century. Berkeley University Press, Los Angeles

Grove RH (1995) Green imperialism: colonial expansion, tropical island edens and the origins of environmentalism, 1600-1860. Cambridge University Press, Cambridge

Hamilton JH (2013) Security: politics, humanity and the philology of care. Princeton University Press, Princeton

Hannig N (2016) The checkered rise of resilience: anticipating risks of nature in Switzerland and Germany since 1800. Hist Soc Res 41(1):240-262

Harrisson M (1994) Public health in British India: Anglo-Indian preventive medicine, 1859-1914. Cambridge University Press, Cambridge

Hulme M (2009) Why we disagree about climate change: understanding controversy, inaction and opportunity. Cambridge University Press, Cambridge

Hünemörder KF (2004) Die Frühgeschichte der globalen Umweltkrise und die Formierung der deutschen Umweltpolitik (1950-1973). Steiner, Stuttgart

Instinsky HU (1952) Sicherheit als politisches Problem des römischen Kaisertums. Verlag für Kunst und Wissenschaft, Baden-Baden

Johnson J (1827) The influence of tropical climates on european constitutions. Underwood, London

Knab C, Forclaz AR (2011) Transnational co-operation in food, agriculture, environment and health in historical perspective. Contemp Eur Hist 20(3):247-255

Kupper P (2003) Die '1970er Diagnose'. Grundsätzliche Überlegungen zu einem Wendepunkt der Umweltgeschichte. Archiv für Sozialgeschichte 43:325-348

Lautensach SW, Lautensach AK (2014) Environmental security. International, national, and human. In: Harris PG (ed) Routledge handbook of global environmental politics. Routledge, London, pp 246-258

Lind J (1811) An essay on diseases incidental to Europeans, in hot climates. Duane, Philadelphia

MacFarlane SN, Khong YF (2006) Human Security and the UN: a critical history. Indiana University Press, Bloomington-Indianapolis

Manen NV (2014) Les plans d'assurance incendie de Goad: cartographie des risques d'incendie et normalisation des risques industriels (1885-1903). Le Mouvement Social 249:163-185

Manulak MW (2015) Multilateral solutions to bilateral problems: the 1972 Stockholm conference and Canadian foreign environmental policy. Int J 70(1):4-22

McCormick T (2016) Who were the pre-Malthusians? In: Mayhew RJ (ed) New perspectives on malthus. Cambridge UP, Cambridge, pp 25-50

Miller SW (2007) An environmental history of Latin America. Cambridge University Press, Cambridge Moniz AB (2006) From empire to humanity: the American revolution and the origins of humanitarianism. Oxford University Press, Oxford 
Monmonier M (1997) Cartographies of danger: mapping hazards in America. Chicago University Press, Chicago

Owens P (2012) Human security and the rise of the social. Rev Int Stud 38(3):547-567

Paris R (2001) Human security: paradigm shift or hot air. Int Secur 26:87-102

Pearson R, Yoneyama T (2015) Corporate forms and organizational choice in international insurance. Oxford University Press, Oxford

Peckham R, Pomfret DM (2013) Medicine, hygiene, and cultures of planning in Asia. Hongkong University Press, Hongkong

Prichard A (2011) What can the absence of anarchism tell us about the history and purpose of International Relations? Rev Int Stud 37:1647-1669

Quenet G (2005) Les tremblements de terre aux XVIIe et XVIIIe siècles. La naissance d'un risque. Époques, Seyssel

Rajan R (1998) Imperial environmentalism or environmental imperialism? European Forestry, colonial foresters and the agendas of forst management in British India 1800-1900. In: Grove R (ed) Nature and the orient. Oxford University Press, Oxford-Delhi, pp 324-371

Rajan SR (2006) Modernizing nature: forestry and imperial eco-development, 1800-1950. Oxford University Press, Oxford

Rivière Y (2007) L'Italie, les îles et le continent: Recherches sur l'exil et l'administration du territoire impérial (Ier-IIIe siècles). In: Van Wees $\mathrm{H}$ et al., Sécurité collective et ordre public dans les sociétés anciennes. Fondation Hardt, Vandœuvres-Geneva, pp 261-309

Robin L (1997) Ecology: a science of empire. In: Griffiths T, Robin L (eds) Ecology and empire: environmental history of settler societies. Keele University Press, Edinburgh, pp 63-75

Rohr C (2007) Extreme Naturereignisse im Ostalpenraum. Naturerfahrung im Spätmittelalter und am Beginn der Neuzeit. Böhlau, Cologne

Rothschild E (1995) What is Security? Daedalus 124(3):53-98

Sallares R (1996) The ecology of the ancient greek world. Duckworth Press, London

Schmidt S (2011) To order the minds of scholars: the discourse of the peace of Westphalia in international relations literature. Int Stud Quart 55(3):601-623

Schmoll F (2004) Erinnerung an die Natur. Die Geschichte des Naturschutzes im deutschen Kaiserreich. Campus, Frankfurt/M

Schröder TJ (2006) Rechtsbildung im wirtschaftlichen 'Weltverkehr'. Das Erdbeben von San Francisco und die internationale Standardisierung von Vertragsbedingungen (1871-1914). Klostermann, Frankfurt/M

Schuck C (ed) (2011) Security in a changing global environment: challenging the human security approach. Nomos, Baden-Baden

Schulz-Walden T (2013) Anfänge globaler Umweltpolitik: Umweltsicherheit in der internationalen Politik (1969-1975). Oldenbourg, Munich

Sellers C (1997) Hazards of the Job: from industrial disease to environmental health science. University of North Carolina Press, Chapel Hill

Sellers C, Melling J (eds) (2011) Dangerous trade: histories of industrial hazard across a globalizing world. University of Pennsylvania Press, Philadelphia

Shakespeare W (1955) Julius Caesar, ed. Dorsch T (The Arden Shakespeare). Routledge, London

Shakespeare W (1984): Macbeth, ed. Muir K (The Arden Shakespeare). Routledge, London

Sieferle R (2001) The subterranean forest: energy systems and the industrial revolution [German ed. 1982]. Cambridge Scholar Press, Cambridge

Sivaramakrishnan K (2008) Science, environment and empire history: comparative perspectives from forests in colonial India. Environ Hist 14:41-65

Speek S (2014) Ecological concepts of development? The case of colonial Zambia. In: Hodge J, Hödl G, Kopf M (eds) Developing Africa: concepts and practices in twentieth-century colonialism. Manchester University Press, Manchester, pp 133-154

Stuber M (2008) Wälder für Generationen. Konzeptionen der Nachhaltigkeit im Kanton Bern (1750-1880). Böhlau, Cologne

Tebeau M (2003) Eating smoke: fire in urban America, 1800-1950. John Hopkins University Press, Baltimore

Tilley H (2003) African environments and environmental sciences: the african research survey, ecological paradigms and british colonial development. In: Beinart W, McGregor J (eds) Social history and environments. Oxford University Press, Oxford, pp 109-130

Trepl L (1987) Geschichte der Ökologie. Vom 17. Jahrhundert bis zur Gegenwart. Fischer, Frankfurt/M 
UNSHP (2007) United Nations human settlements programme: enhancing urban safety and security: global report on human settlements. Earthscan, London

UNHSP (2011) United Nations human settlements programme. Global report on human settlements 2011: Cities and Climate Change. Earthscan, London

Wächter HJ (2008) Naturschutz in den deutschen Kolonien in Afrika (1884-1918). LIT, Berlin

Waechter M (1996) Die Erfindung des amerikanischen Westens. Die Geschichte der Frontier-Debatte. Rombach, Freiburg

Walsh MW (2017), How to File a Claim for Flood Damage, In: New York Times https://www.nytimes. com/2017/08/28/business/how-to-file-a-claim-for-flood-damage.html. Accessed 10 Oct 2017)

Weintraub BA (1995) Environmental security, environmental management, and environmental justice. Pace Environ Law Rev 12:614-618

Wöbse A (2011) 'The world after all was one': the International Environmental Network of UNESCO and IUPN, 1945-1950. Contemp Eur Hist 20(3):331-348

Worster D (1994) Nature's economy: a history of ecological ideas, 2nd edn. Cambridge UP, Cambridge

Yeoh BS (1996) Contesting space: power relations and the urban built environment in colonial Singapure. Oxford University Press, Oxford

Zwierlein C (2011) Der gezähmte Prometheus. Feuer und Sicherheit zwischen Früher Neuzeit und Moderne. Vandenhoeck \& Ruprecht, Göttingen, pp 306-314

Zwierlein C (ed.) (2012) Sicherheit und Epochengrenzen, special issue Geschichte \& Gesellschaft 38, 3

Zwierlein C (2013) Security politics and conspiracy theories in the emerging european state system (15th/ 16th c.). Hist Soc Res 38:65-95

Zwierlein C (2017) Perceiving urban fire regimes in Europe and China (1830 to 1870): British fire insurance business and the sudden challenge of globalization. In: Schenk GJ (ed) Hist Disaster Exp. Springer, Heidelberg, pp 327-352

Zwierlein C, Graf R, Ressel M (2010) The production of human security in premodern and contemporary history. Hist Soc Res 35:4 (special issue) 